\title{
FILM-STUDY AS A SOURCE OF FORMATION OF CREATIVE CROSS-CULTURAL SKILLS IN MULTICULTURAL CONTEXT
}

\author{
Liudmila STAROSTOVA ${ }^{1}$, Larisa PISKUNOVA ${ }^{2}$ \\ Ural Federal University, \\ ${ }^{1}$ Institute of Public Administration and Entrepreneurship, \\ Department of Marketing Communications and Branding \\ Lenina ul. 13b, Yekaterinburg 620014, Russia \\ ${ }^{2}$ Ural Federal University, \\ Institute of Social and Political Sciences \\ Lenina ul. 51, Yekaterinburg 620000, Russia \\ E-mails: 'starostova5@mail.ru (corresponding author); ${ }^{2}$ reklama-urgu@yandex.ru
}

Received 14 September 2015; accepted 23 December 2015

\begin{abstract}
The authors propose to look at the cinema in the education process in terms of its potential use as a tool of formation of creative cross-cultural competence. Nowadays cinema is not just a synthetic art, it is deeply integrated into the basic structure of modern culture, and forms means capable of becoming an effective source of educational innovations.

The article proposes the concept of film-study as a reference for the complex of methodical use of cinema in education. Analysis of different cases of inclusion of cinema in practical lessons allowed the authors to substantiate the connection of film-study method with the formation of students' creative cross-cultural skills. As stated in the article, techniques of film-study method used by the authors contribute to the development of students' cross-cultural competence relevant in a multicultural context of their professional and daily activities.
\end{abstract}

Keywords: cinema, creative cross-cultural skills, education, film, film-study, multicultural context, teaching method.

\section{Introduction}

Traditional pedagogy is focused mainly on the development of logical-mathematical abilities, verbal skills, i.e., left brain thinking. Traditional forms of teaching (lectures, seminars) orient students primarily to reproduce what they have heard. At the same time, it is necessary to take into account the specificity of thinking of today's youth (clip-like, file, visual thinking), which is immersed into a special communication space that transforms their thinking abilities and ways of handling (processing) information (McLuhan 1994; Mitkus 2013; Frumkin 2010; Rosen 2007). 
These factors of modern education environment come into conflict with the requirements of the labor market. Modern economies require the following from workers: ability to make decisions, think and act in the proposed circumstances, be mobile in mastering information. Speaking about the specifics of work in the post-fordist economy, André Gorz writes that modern workers "need to bring into the work process their entire cultural baggage acquired in games, in team sports and music competitions, in debates [...]", since these practices allow workers to develop a mental alertness, the ability to improvise and cooperate (Gorz 2010: 27).

The authors of the concept of creative economy (Landry 2000; Florida 2002) also note a significant increase in the proportion of creative activities in modern economy. Therefore, in their opinion, the role of skill to generate new knowledge is enhanced in many professions (in comparison with the traditional skill of acquiring knowledge). This skill in the future will become more urgent as terms for "work" of ideas that bring competitive advantage are constantly shrinking.

In the context of globalization in many sectors of the economy there is going the process of internationalization of professional activity, more deeply in the part that is mostly in contact with communications. Therefore, the labor market demand for cross-cultural competence of graduates is growing.

The purpose of this article is to substantiate the importance of applying of filmstudy method for the development of students' cross-cultural skills relevant in a multicultural context of their professional and daily activities.

\section{Creative cross-cultural skills in modern conditions}

The notion of cross-cultural competence has become a subject of study for a number of authors (Hanvey 1982; Kizim, Soboleva 2013; Lapshin 1999; Sadokhin 2004). We are closer to the definition made by Anatoly Kizim and Victoria Soboleva who treat cross-cultural competence as:

"a kind of an international phenomenon in the economic and civil sphere, which is defined by knowledge of the peculiar characteristics of the various national cultures, understanding of how the various elements of the culture linked to behavior consumers and influence their actions, and also includes the ability on the basis of this knowledge to develop and implement marketing strategies and programs to ensure maximum return in the context of a particular culture" (Kizim, Soboleva 2013: 182).

As we can see, cross-cultural competence is a set of professional skills, which provide effective work in cross-cultural environment. It is not just knowledge of national socio-cultural characteristics and readiness to take them into account in building communication, but also flexibility in interpersonal interaction, ability to make quick decisions in a changing (and perhaps unpredictable) situation. We are responsible for our existential creativity, which itself will be subject to the interpretation of the members of the community to which we belong in the future (Kačerauskas 2010: 36). Multicultural environment creates new challenges for professionals today. As a result, we see today the growth of research interest in the phenomenon of creativity (Florida 2002; Pine, Gilmore 1999; Ridderstråle, Nordström 2002; Wood 2004). 
The philosophical justification of education aimed at shaping creative thinking personality was formulated almost 100 years ago as part of the philosophy of pragmatism - by the father of modern American pedagogy John Dewey. The key concept of the pragmatism philosophy is experience. It serves as the fundamental basis on which Dewey built the concept of education: education consists primarily in the transfer of knowledge through communication. In this regard, Dewey defines education as follows: restructuring or reorganizing of experience that expands its meaning and enhances human ability to choose a direction for further experience (Dewey 1985).

To achieve these goals, Dewey developed a number of recommendations on education; the main ones are requirements to avoid an abstract or global formulation of the question, always put the problem in the particular circumstances, emotionally engage students in the educational process.

The result of education should be the developing of thinking skills, which are understood as the ability of primarily self-learning. Graduates of education institutions should be able to cope with life's challenges on their own, possess modern experience, which refers to knowledge as such, and knowledge of the ways of working in different situations, and have generated the need for self-learning and self-improvement.

Therefore, innovative activity of the person is both the possibility of self-affirmation and protest against established standards, values and traditions. Psychologically, innovative behavior is very uncomfortable; it is associated "with the functioning of the individual in permanently arising extreme situations. There is enormous risk, liability, uncertainty and unpredictability" (Kravchuk 2011). Otherwise, creativity is flexibility, the ability to stay ahead of time, "the ability to create new meanings and new values" (Zelentsova, Gladkih 2010: 78).

Friday O. Okpara distinguishes three components in the individual which underlie creativity: expertise, creative thinking skills and motivation. According to his opinion, the skills of creative thinking lay in the approach to solve problems and in the ability of new match of existing ideas with each other (Okpara 2007).

Considering all aforementioned, it seems of current interest to search and study new learning technologies to develop students' skills in creative thinking and operating in conditions of fuzzy logic, which helps to prevent many of the fears associated with the uncertainty in decision-making process.

Art has a high educational potential in this respect: "art may have different didactical purposes: educating, cultivating, communicating, provoking critical reflection, communicating, disciplinating bad behavior, agitating for ideal conduct toward nature, manipulating attitudes etc." (Juzefovič 2015: 18). These technologies are less formalized and involve the use of a wider range of activities in learning process, often far removed from the production routine. If the mosaic information environment destroys traditional forms of mental operations, replacing them with the new ones, education cannot help but understand and use the fragmented cultural field as a new form of communication. According to Kirill K. Naydenyshev, we are witnessing a change in the basic principle of knowledge formation: "Today, the formation of knowledge is done, first of all, with the help of the mass media and not through education, 
as it was in the traditional humanitarian culture" (Naydenyshev 2011: 149). Moreover, the movie still holds a leading position in terms of interest for a part of the audience (Fokht-Babushkin 2008: 120-126).

If a student is more involved in cinema communication than in book culture, access to the movies as an educational resource becomes inevitable. Means of artistic culture (in particular cinema) can be effectively used for development of intuition and lateral thinking. It develops analytical, reflexive, interpretive work skills, which could be enhanced by emotional immersion in learned material. Screening and discussion of films is becoming one of the means of fast growing popularity.

\section{Film-study as an education source}

The need to include the cinema experience into the education process is dictated by the specific nature of contemporary culture that is saturated with media communications, and forms the phenomenon of clip-like consciousness. The predominance of visual images in the total information has a systemic impact on human consciousness. The younger generation often has difficulty with working with textual information; they prefer video substitutes to text sources. For them the linear text narrative is less familiar than the montage connections which create the meaning of video.

Many books have been written on the nature of cinema for more than a hundred years of its development (for example, see Kracauer 1960; Eisenstein 2000; Deleuze 2004; Lotman 1973). Different aspects of the existence of the cinema phenomenon from the structural and expressive resources of the film to the ways of its interaction with different audiences, and inclusion in the social and cultural context were the subject of the judgment in them.

Experience of referring to cinema as methodological resource is quite rich. For example, the film by Michelangelo Antonioni Red Desert (1964) has caused, in its time, great interest to psychiatrists as a descriptive illustration of neurotic processes (Bogemskiy 1992: 133). Jungian psychology also considers artistic practice, and in particular cinema, in terms of credibility of lighting of various psychological states which the heroes of art go through in dealing with difficult situations. As Luke L. Hockley emphasizes, "all what we are experiencing in the film is the awakening of personal and collective psychological material that reflects the characteristic behavior of images in the mind" (Hockley 2010: 26).

Formally, the film almost simultaneously collects in huge cinemas a large number of people; meaningfully, cinema accumulates questions, stories, topics of concern to the mass of people. Yuri Lotman had called attention to the deep integration of the cinema in the social, political, moral processes of the epoch. Soaking up the nerve of social conflicts, the cinema conveys it to audience:

"film belongs to the ideological struggle, culture and art of his era. With these sides it is associated with numerous aspects of life and it generates a train of values, which for a historian and contemporary are sometimes more important than the actual aesthetic problems" (Lotman 1973: 54-55). 
Its creators, i.e. directors, paid great attention to constructive and expressive possibilities of cinema. If Sergei Eisenstein and Dziga Vertov practically and theoretically mastered mounting possibilities in the design of film narration, Andrei Tarkovsky explored time as a way to create a movie directly texturing feeling of reality, Orson Wells worked with the space frame (which are just a few names from a long snatched a number of innovative discoveries in the movie); the spectator-analyst, in turn, was able to see the film with the help of the world hitherto unrevealed his patterns and structures. Cinema is a product of artistic sense, but because of its masterful load shape it creates additional prerequisites for the formation of a critical view of information sources, taking into account the ways of constructing the message in the transmission process. When we use the movie as a methodological tool in learning process, we should not forget that film serves not only as an illustrator, but as a problem field which itself requires a critical assessment. As a product and the representative of the modern culture, cinema has become an important indicator of the time. In particular, Agnieška Juzefovič considers cinema as a fruitful informational resource in study of the city in which it was filmed (Juzefovič 2011: 86).

Some authors have considered the issue of the use of products of modern mass culture in teaching (see Griffin 2015; Champoux 1999; Weinacht et al. 2009; Cappelletti et al. 2007). Em Griffin in his book Communication gives a fairly extensive list of films which can be used as illustrations of individual sections of the communication theory (Griffin 2015: 680-683). And although the author considers cinema as illustrative material to the theory of communication, the distribution of films on various theoretical approaches to the problem of communication that he has made, proves the thesis about the variety of potential of using cinema as a case.

Joseph E. Champoux (1999) has systematized and classified uses of cinema in education process by providing such forms of methodical use of film as a case, a metaphor, a symbol, etc. It allowed him to reveal the diversity of the integration of film material in learning process.

We propose to use the concept film-study as a synthesis of all the possible ways to integrate the movie into learning process. The concept of film-study combines a wide range of methods of using cinema-products in education to improve the efficiency of mastering new material by the students.

\section{Methods of using film-study to contribute to the formation of creative cross-cultural competences}

In this section of the article, we will describe the basic techniques of film-study method used in our learning process.

Film-study as a didactic method has been used by us in learning process for several years (disciplines "Consumer Behavior", "Organizational Behavior", "Marketing Communications", "Cultural and Economic Anthropology", which are read for students of humanities and manager majors).

In the standard training course (subject to 54 hours, including 18 hours devoted to lectures and 36 hours devoted to seminars), in case of using the method of film- 
study, an average of two thirds of the time of seminars are devoted to the analysis and interpretation of visual material (films, commercial advertising). In the first lesson, goals and objectives of the course are formulated, practical learning outcomes and ways to achieve them are described, that is, in the introduction to the course a set of competencies that will be formed through a variety of teaching methods (including film-study) is fixed.

Below, we consider some cinema tools used by us in the education process (video case, experiment, metaphor, symbol):

1. The most obvious way to work with a movie in the classroom is movie as video case. It refers to specific situations, to the image of human behavior in a situation of choice. When it comes to humanitarian, manager studies, almost every cinematic scene can be used to illustrate the problematic question on the theory of decision-making, conflict resolution, establishing communications, research outputs of stress, leadership behavior.

As an example, film The Guardian (2006, director Andrew Davis) is very illustrative. As a video case it is used in the course study "Organizational Behavior" to discuss such topics: leadership, trunking, typology of conflicts. After watching the film, students are given the task based on the theoretical material typology, to classify and model leadership behavior of movie protagonists, reveal the specifics of the various types of conflicts. Film as video case through work with specific examples allows avoiding excessive didacticism in the value assessment of the situation where a person is facing a serious existential choice.

The aims of using cinema as a case for situation analysis may be the following:

- development of critical thinking skills;

- connection of theory and practice;

- presentation of examples of concrete decisions;

- demonstration of different points of view;

- formation of skills of assessment of alternatives under conditions of uncertainty;

- teaching students, both individually and as a group: to analyze the information, to sort it for solving a given problem, to identify key issues, to generate alternative solutions and evaluate them to select the best solution and to form action programs, etc.

In addition to these objectives, additional effects, namely learned ones, may be achieved in applying the analysis of situations:

- receiving communication skills;

- developing presentation skills;

- forming interactive skills to effectively interact and take collective decisions;

- acquiring the expertise skills;

- learning to learn, to find the necessary knowledge to solve situational problems.

Thus, the cinema-as-the-case-technology is an interactive technology for training on the basis of real or fictional situations, aimed not so much at memorization of 
training material, but at the formation of the students' new skills. One of the major characteristics of the cinema-as-the-case method is the ability to use the theory in the analysis of factual material. However, its main purpose is to develop the ability to find a solution to the problem, learn how to work with information. By using cinema fragments, which contain a fascinating story, brilliant directing and acting, drama and intrigue in the presentation of the material, as a case study we can hope that all of these attributes of the film would impact students much greater than the standard textual case;

2. During the lesson film is often used in place of printed materials as a training exercise, or a kind of experiment. In contrast to the methods of recording only what already exists, the experiment in teaching has a constructive character. It is a controlled study observation, during which the process is fixed, which is specifically "run". Analysis of the film in this case is more productive in small groups, by offering students a theoretical pre-reader book. According to the developed theoretical matrix, individual and group skills management decisions are modeled on the basis of the film.

The experience of work with the film The T-Shirt (2006, director Hossein Martin Fazeli) within the course "Cross-Cultural Management" can serve an illustration of the method of film-study as experiment. This film, completed with examples from work with ethnic stereotypes in everyday life, folklore and media messaging, allows visually revealing the nature and form of the impact of stereotypes on business communication in a multicultural environment. Visual material of the film is complemented in this case with work with texts of proverbs and sayings, news media reports, anecdotes, fixing ethnic stereotypes and denoting a certain world-image.

The reliability of the experimental findings is directly related to understanding the conditions of the experiment, to the reality where students are. In the case of film, this translates into the need to clearly understand the contextual conditions for the development of situation and the degree of its adequacy to the reality in which the student is (social, political, legal and other contexts);

3. Particular importance in the method of film-study belongs to the use of cinema as a metaphor. Metaphors are a key marker of artistry. Works of literature and cinema through metaphor acquire versatility and multiple meanings, vibrancy, brightness and performance; they creatively depict phenomena of everyday life.

The effectiveness of metaphor in education and in practical life is due to clearness of the statements, consonance with the situation, contextuality, avoiding platitudes and edification when discussing work situations.

The high importance of using metaphors in the pedagogical process is determined by a number of its characteristics. Due to the transfer of meanings metaphor allows expressing the inexpressible, gives dramatic effect to utterance, makes imagery in dry abstraction (Lakoff, Johnson 1980). The vital function of metaphor is the stimulation of imagination and creative thinking of the perceiver. We want to emphasize the following possibilities of using metaphors in teaching: 
- it activates mechanisms of imagination, perception, memory, so, it promotes the development of creative abilities of students; develops their thinking through the process of finding the relationship between the objects of reality;

- it allows to perceive the information in the light of comparative analysis of the reality and fiction (film); expands students' semantic space;

- it contributes to its interpretation of the values, meanings, sayings, both of the fictional characters in the film and the real people and the establishment of associations on the basis of the obtained visual information.

In the movie Modern Times (1936, director Charlie Chaplin), we see clear manifestations of metaphor through satirical show of conveyor assembly line. It depicts the physical defects of people arising from constantly repeated action, shows how the assembly line produces ugly behavior of workers. Once showing, you can use this memorable image as a symbol of industrial world. This image is most often used in the courses of "Economic Anthropology" and "Organizational Behavior" by the disclosure of the following topics: "man as an element of social and economic systems", "Fordist and post-Fordist economy: the challenge of transformation";

4. Close to metaphor is the use of movie images as symbols. Signs and symbols surround people everywhere since their birth. Understanding reality through a set of associative keywords, signs, colors and other supports for thought is a very relevant skill in today's life. This skill can help a person to instantly retrieve previously known and understandable information by referring to symbolic reality.

Below we have listed the advantages of a symbol as a means of expression:

- it is concise and at the same time there is a variety of associative series, which gives richness and inexhaustible interpretations, and hence a deeper reflection of reality;

- it is structuralism. Education drawing on symbols develops systematic thinking, allows dividing the total and the main, seeing the causal connection;

- availability of conveying information;

- a variety of symbolic visual information facilitates the storage of the material by connecting visual memory.

Some movie scenes offer a symbolic method of connecting theory to practice. The film is an excellent medium for interpretation of the meaning of the theories and concepts. Visual and sound film effects convey a sense of the imaging better than printed text. In the film 12 Angry Men (1997, director William Friedkin), disputes of the characters convey the conflict much more voluminous than its description. The value of the moment is revealed by a non-linear sequence of scenes, via the impact of context, intonation, through the inclusion of facial expressions and gestures of the characters into the scene. Using the expressive vocabulary, symbolic and other multi-valued designs makes the movie a "bulk illustration" and explains the essence of theoretical material much more clearly and contributes to more "emotional" assimilation.

Fancy frames, their sequence, lighting, black and white photography, camera angles often refer to the symbolism of what is happening. The film Ikiru (1952, dir- 
ector Akira Kurosawa) shows a series of scenes with officials-bureaucrats transmitting some of residents to the service of state administration. Black-and-white photos and a special sequence of scenes give the film a symbolic meaning, and fix the viewer's attention to malfunction, slowness, rigidity of the bureaucracy.

From the point of view of the formation of cross-cultural competence, cinema is particularly important as a reflection of culture of different countries, experience of different people, generations and eras. Each film is required to present cross-cultural embedding, referring to the values and behavioral characteristics of people of other cultures and countries, providing experience of perceiving the other, experience with the countries in which the man was not. Comparisons and remakes of films allow you to see the dynamics of culture. That is, the film text is a complex of communicative formation, and has a number of interdiscursive relations within its own culture.

\section{Integrated use of film-study method in teaching of "Organizational Behavior" course}

This section of the article describes the experience of practical use of cinema in the education process and the results of evaluation of this method of teaching.

For a descriptive representation of complex application of the film-study method we can give an example of its use in teaching the course "Organizational Behavior", in particular, the theme "Corporate Culture". The key to our analysis is the relationship of the studied competences with the methods of film-study.

The main problem in the topic "Corporate Culture" is the specificity of the interaction of man/employee and corporate standards/culture of the organization. The degree of involvement and dissolution of man in company is shown, with the growing characteristic, in the following films: Fight Club (1999, director David Fincher), The Devil Wears Prada (2006, director David Frankel), Up in the Air (2009, director Jason Reitman), Margin Call (2011, director J. C. Chandor). Review and discussion of these films enables us to generalize the experience of the heroes of these jobs, and to answer the most important for any manager question: how to avoid becoming a slave to the corporate culture and remain a human? A comparison of texts of different movies in one theme allows fixing the semantic dynamics of the phenomenon depending on the context/story, the story being told.

The combination of visual and semantic material of these films with the theoretical texts allows us to consider a range of issues in the field of management: employee motivation, goal-setting of staff and manager, value aspects of management, principles of group forming, conflicts and practice of working with them. The search for the answers to the following questions goes on during the discussion of films:

- how employees relate to their work and to the company as a whole;

- what problems are worrying a person, what he prioritizes in his decision, which methods and ways of solving them have been used;

- how teamwork has been built; what determines the differences in behavior (ethnicity, culture, religion); 
- what is the system of motivation of employees;

- what approaches in management have greater impact.

Films form in students a sense of time, showing various aspects of management, organizational behavior, behavioral strategies, human forms and methods of communication in the historical dynamics, focusing on language problems (both linguistic and semantic), the admissibility of various forms of physical contact, practices of displaying/hiding emotions and specific non-verbal communication of representatives of different nationalities.

Movies Bonus (1974, director Sergey Mikaelyan) and Fear and Trembling (2003, director Alain Corneau) allow to select the cross-cultural aspect of the study of corporate culture. In the film Bonus, which refers to the Soviet reality, descriptive languages of industrial conflict (failure to receive an award for outstanding work) are clashing; the victim is changed several times in the dispute; there is a collision of "the worlds of justification". The film shows that the language of economics is not the only possible language to describe the situation, and in this sense the economy is one of many explanatory constructs of social reality and not the ultimate truth. Economic categories of "payment", "efficiency", "cost" turn into the category of morality and face value of such non-economic phenomena as family and friendship. This film helps to bring a discussion about contingency of management decisions and human moral choice without undue didacticism.

The film Fear and Trembling, dedicated to the collision of two corporate logics Japanese (demonstration of obedience and respect) and European (result-oriented, rationality), is even more multifaceted than Bonus. The film has very well shown that in different cultures the same action is often treated the opposite way on the basis of the value of legitimation (a "Western pragmatism") or Japanese "dignity and face".

For three years, from 2013 to 2015, we collected the students' opinion about the effectiveness of the film-study method. In total, more than two hundred people left their responses. Most of the students positively assess the practice of using cinema as an educational resource that provides a basis for conclusions about the adjustment of teaching method in accordance with the perceptions and demands of students.

In the questionnaire containing open-ended questions, students were asked to indicate which competencies they would like to learn in the course "Organizational Behavior". They also evaluated the methodology by formulating the perceived benefits. The final part of the questionnaire offered students to characterize techniques of the film-study method.

Table 1, made on the basis of completed students questionnaires, summarizes the evaluation (perceived benefit) of methodology and contains the highlighted essential elements of the new methodological technique: 
Table 1. Perceived advantages of film-study method and desired competences

\begin{tabular}{|c|c|c|}
\hline Desired competences & $\begin{array}{l}\text { Evaluation of the method (per- } \\
\text { ceived benefits) }\end{array}$ & $\begin{array}{l}\text { Film-study method techniques } \\
\text { perception }\end{array}$ \\
\hline $\begin{array}{l}\text { The ability } \\
\text { to conduct } \\
\text { communication }\end{array}$ & $\begin{array}{l}\text { The discussion in the classroom, } \\
\text { in-depth understanding of the } \\
\text { material. } \\
\text { Cinema is more easily } \\
\text { comprehended than texts. } \\
\text { There are ready images to } \\
\text { exchange views. }\end{array}$ & $\begin{array}{l}\text { Visibility, accessibility. } \\
\text { It makes you wonder. }\end{array}$ \\
\hline Independent thinking & $\begin{array}{l}\text { Ability to comprehend problems } \\
\text { independently. } \\
\text { When watching movies at home } \\
\text { there is the time for independent } \\
\text { analysis. }\end{array}$ & $\begin{array}{l}\text { The ability to debate and look } \\
\text { at the situation from different } \\
\text { perspectives. }\end{array}$ \\
\hline Management skills & $\begin{array}{l}\text { Objective picture, a new look } \\
\text { on certain things, analysis and } \\
\text { comparison. } \\
\text { Visibility, someone else's } \\
\text { experience allows understanding } \\
\text { the problem. }\end{array}$ & $\begin{array}{l}\text { Visualization of the issues and } \\
\text { reinforcement of knowledge. }\end{array}$ \\
\hline $\begin{array}{l}\text { The ability to look at } \\
\text { different sides of the } \\
\text { issue }\end{array}$ & $\begin{array}{l}\text { Different sided material for } \\
\text { problem discussion. } \\
\text { Relating the situations in the film } \\
\text { to those in life. }\end{array}$ & $\begin{array}{l}\text { Multi-sided presenting of the } \\
\text { material. } \\
\text { Non-standard techniques. }\end{array}$ \\
\hline $\begin{array}{l}\text { Rhetoric, the ability } \\
\text { to listen to the } \\
\text { interlocutor }\end{array}$ & $\begin{array}{l}\text { Accessibility, clarity and } \\
\text { understandability of the films for } \\
\text { illustration of own theses during } \\
\text { the discussion. }\end{array}$ & $\begin{array}{l}\text { Faster and clearer in the } \\
\text { assimilation of the material. }\end{array}$ \\
\hline $\begin{array}{l}\text { Simulations to make } \\
\text { decision }\end{array}$ & $\begin{array}{l}\text { Live examples of analysis of work } \\
\text { situations, visual scene material. }\end{array}$ & $\begin{array}{l}\text { Tool of involvement in the } \\
\text { discussion of all participants. The } \\
\text { impetus for the formation of an } \\
\text { independent point of view. }\end{array}$ \\
\hline
\end{tabular}

Source: created by authors.

Thus, the most important advantages of the method of film-study include the following: the visibility, accessibility, interest, speed of learning material, the versatility and diversity formulation of the problem, originality, lack of didacticism. Using the method enables interactivity in the classroom, interaction of students and enabling them to actively discuss operational issues. Among these competences mentioned by students we can relate at least two to creative competences: simulation of situations and the ability to look at the different sides of the issue.

Table 2 shows the ratio of competency requirements for specialists, tools of their formation and the expected results, both from the basis of education standards, and from professional practice as well as methodological advantages of film-study and formed creative cross-cultural competences. 
Table 2. Correlation of creative cross-cultural skills and tools for their formation within the film-study method

\begin{tabular}{|l|l|l|}
\hline \multicolumn{1}{|c|}{$\begin{array}{c}\text { Creative cross-cultural } \\
\text { skills }\end{array}$} & The mechanism of the film-study & \multicolumn{1}{c|}{ Expected results } \\
\hline $\begin{array}{l}\text { 1. The ability to respond } \\
\text { to changing contexts of } \\
\text { activities and actively } \\
\text { influence the situation, } \\
\text { depending on the specific } \\
\text { task. }\end{array}$ & $\begin{array}{l}\text { Simultaneous presence in the } \\
\text { frame of the "text" and "con- } \\
\text { text", the transition from linear to } \\
\text { configurations }\end{array}$ & Adaptability. \\
\hline $\begin{array}{l}\text { 2. The ability to go bey- } \\
\text { ond the usual behavioral } \\
\text { model in a multicultural, } \\
\text { professional environment. }\end{array}$ & $\begin{array}{l}\text { Cinema image allows us to cap- } \\
\text { ture the image of the whole real- } \\
\text { ity in an instant. } \\
\text { Recipient's empathy towards the } \\
\text { explained material/situation al- } \\
\text { lows using emotions, a symbolic } \\
\text { range in the explanation of human } \\
\text { behavior. }\end{array}$ & $\begin{array}{l}\text { Skills of anti-stress behavior. } \\
\text { activities of the other, to join } \\
\text { him in an active interaction (at } \\
\text { the level of interpretation and } \\
\text { reflection). }\end{array}$ \\
\hline $\begin{array}{l}\text { 3. Understanding the } \\
\text { world from different per- } \\
\text { spectives; explanation of } \\
\text { its versatility, complete- } \\
\text { ness and inconsistencies. }\end{array}$ & $\begin{array}{l}\text { During the discussion of the film } \\
\text { the alternatives of the story that } \\
\text { provides student's interest to situ- } \\
\text { ations/information/material are } \\
\text { acted out. }\end{array}$ & $\begin{array}{l}\text { Mastering different languages } \\
\text { to describe reality. } \\
\text { Flexibility of thinking. }\end{array}$ \\
\hline
\end{tabular}

Source: created by authors.

In Table 2, we have combined the main of the above mentioned creative cross-cultural skills to the identified by us specificity of the film-study method and the expected results. As table 2 shows, communication resources of this method can act as an effective link between creative cross-cultural skills and learning outcomes.

Table 3 summarizes the distribution of films have been used by us in selected academic disciplines.

Table 3. List of films commonly used in teaching the disciplines of management cycle

\begin{tabular}{|l|l|}
\hline \multicolumn{1}{|c|}{$\begin{array}{c}\text { Academic } \\
\text { discipline }\end{array}$} & \multicolumn{1}{c|}{ Films used in teaching the discipline } \\
\hline $\begin{array}{l}\text { Cross-Cultural } \\
\text { Management }\end{array}$ & $\begin{array}{l}\text { The T-Shirt (2006, director Hossein Martin Fazeli): case, metaphor, symbol; } \\
\text { Fear and Trembling (2003, director Alain Corneau): case, experience, } \\
\text { symbol. }\end{array}$ \\
\hline $\begin{array}{l}\text { Organizational } \\
\text { Behavior }\end{array}$ & $\begin{array}{l}\text { The Guardian (2006, director Andrew Davis): case, experience, } \\
\text { experiment; } \\
\text { The Wave (2008, director Dennis Gansel): case, experiment, experience; } \\
\text { Exam (2009, director Stuart Hazeldine): experiment, experience; } \\
\text { Modern Times (1936, director Charlie Chaplin): metaphor, symbol; } \\
\text { Fight Club (1999, director David Fincher): experience, symbol; } \\
\text { The Devil Wears Prada (2006, director David Frankel): experience, symbol; } \\
\text { Up in the Air (2009, director Jason Reitman): experience, symbol; } \\
\text { Margin Call (2011, director J. C. Chandor): experience, symbol. }\end{array}$ \\
\hline
\end{tabular}


End of Table 3

\begin{tabular}{|l|l|}
\hline \multicolumn{1}{|c|}{$\begin{array}{c}\text { Academic } \\
\text { discipline }\end{array}$} & \multicolumn{1}{c|}{ Films used in teaching the discipline } \\
\hline $\begin{array}{l}\text { Economic } \\
\text { Anthropology }\end{array}$ & $\begin{array}{l}\text { Bonus (1974, director Sergey Mikhaelyan): case, experience; } \\
\text { Fear and Trembling (2003, director Alain Corneau): case, symbol; } \\
\text { There Will Be Blood (2007, director Paul Thomas Anderson): experience, } \\
\text { metaphor; } \\
\text { Just like that (1976, director Stella Aristakesova): metaphor, symbol; } \\
\text { Vodka Lemon (2003, director Huner Saleem): experience, symbol; } \\
\text { Ikiru (1952, director Akira Kurosawa): experience, symbol; } \\
\text { 12 Angry Men (1997, director William Friedkin): experience, metaphor. }\end{array}$ \\
\hline $\begin{array}{l}\text { Consumer } \\
\text { Behavior }\end{array}$ & $\begin{array}{l}\text { The Paradise (TV series) (2012, directors David Drury, Marc Jobst, Susan } \\
\text { Seduction in the City: The Birth of Shopping (2010, director Sally Aitken): } \\
\text { case, experience; } \\
\text { The Devil Wears Prada (2006, director David Frankel): metaphor, symbol; } \\
\text { The Joneses (2010, director Derik Borte): experiment, experience, symbol; } \\
\text { Glyanec (2007, director Andrei Konchalovsky): metaphor; } \\
\text { Sex and the City (TV series, directors Michael Patrick King and others): } \\
\text { experience, symbol. }\end{array}$ \\
\hline
\end{tabular}

Source: created by authors.

We do not consider the list of films shown in Table 3 as being full. We have put in Table 3 only core set of films, which are used by us in teaching the disciplines indicated in the table. Each film is accompanied by a remark about in what educational format (experiment, metaphor, etc.) this film is most useful for the development of creative cross-cultural skills.

\section{Conclusions}

It can be stated that the practice of innovative education methods draws the boundaries of the new didactic method - film-study. This method has already proven its effectiveness as a means of increasing the digestibility of education material by students. At the same time, our experience in teaching the subjects of managerial and economic profiles, as well as those in the field of communication shows that in the formation of creative cross-cultural competencies which are required to operate effectively in multicultural environments, film-study demonstrates the high efficiency.

We are convinced that cross-cultural competence is formed by a complex of subjects by comparing different cultural situations, contexts, logics and languages explaining the reality presented both in text format and in images. This is due to the fact that the cinema as a means of communication allows us to convincingly illustrate the richness of life situations. In addition, cinema has the resources of problematization of life material and is constantly evolving arsenal of tools to concentrate audience's attention. 


\section{References}

Bogemskiy, G. 1992. Identifikatsiya mastera, Iskusstvo kino 10: 131-138.

Cappelletti, G. L.; Sabelli, M. J. G.; Tenutto, M. A. 2007. Can We Teach Better? The Relationship between the Cinema and Teaching, Journal of Medicine and Movies 3: 87-91.

Champoux, J. E. 1999. Film as a Teaching Resource, Journal of Management Inquiry 8(2): 206217. http://dx.doi.org/10.1177/105649269982016

Deleuze, G. 2004. Kino. Moscow: Ad Marginem.

Dewey, J. 1985. Democracy and Education, in Boydston, J. (Ed.). The Middle Works of John Dewey, 1899-1924. Vol. 9: 1916. Carbondale, IL: Southern Illinois University Press.

Eisenstein, S. 2000. Montazh. Moscow: Eisenstein-Tsentr, Muzey kino.

Florida, R. 2002. The Rise of the Creative Class: And how It Is Transforming Leisure, Community and Everyday Life. New York: Basic Books.

Fokht-Babushkin, Y. U. 2008. Vzaimodeistvie kino i publiki v kommunikativnoi systeme khudozhestvennoi kulturi, in Zhabsky, M. I. (Ed.). Kinoprocess v kommunikativnoi perspektive. Moscow: Beliy bereg, 114-151.

Frumkin, K. G. 2010. Klipovoe mishlenie I sudba lineinogo texta, Ineternum 1 [online], [cited 20 April 2015]. Available from Internet: http://nounivers.narod.ru/ofirs/kf_clip.htm

Gorz, A. 2010. Nematerialnoe: Znanie, stoimost i kapital. Moscow: Izdat. Dom gos. Universiteta - Vis. Shkoli economiki.

Griffin, E. 2015. Kommunikatsiya: teorii i praktiki. Kharkov: Gumanitarniy tsentr.

Hanvey, R. G. 1982. An Attainable Global Perspective, Theory into Practice 21(3): 162-167. http://dx.doi.org/10.1080/00405848209543001

Hockley, L. 2010. Kino - illusiya i realnost, in Slepack, K. (Ed.). Kino i glubinnaya psikhologiya: sbornik. Moscow: MAAP, 19-30.

Juzefovič, A. 2011. A Story of Shanghai through the Cinema, Limes: Borderland Studies 4(1): 75-88. http://dx.doi.org/10.3846/20290187.2011.577170

Juzefovič, A. 2015. Creativity and Aesthetic Applied to Ecological Education, Creativity Studies 8(1): 12-24. http://dx.doi.org/10.3846/23450479.2014.1000410

Kačerauskas, T. 2010. Education of Coexistence as Technē Tou Biou, Santalka: filosofija, komunikacija 18(3): 31-39. http://dx.doi.org/10.3846/coactivity.2010.24

Kizim, A. A.; Soboleva, V. V. 2013. Effektivnost marketingovikh vozmozhnostey v kontekste natsionalnikh kultur, Teoriya i praktika obshestvennogo razvitiya 3: 181-186.

Kracauer, S. 1960. Theory of Film: The Redemption of Physical Reality. New York: Oxford University Press.

Kravchuk, P. F. 2011. Vzaimosvyaz i razlichiya ponyatiy "tvorchestvo", "kreativnost”, "innovatsiya”, Izvestiya YZGU: Seriya Ekonomika. Sotsiologiya. Menedzhment 1: 126-133.

Lakoff, G.; Johnson, M. 1980. Metaphors We Live By. Chicago: University of Chicago Press.

Landry, Ch. 2000. The Creative City: A Toolkit for Urban Innovators. London: Earthscan.

Lapshin, A. G. 1999. Mezhdunarodnoe sotrudnochestvo v oblasti gumanitarnogo obrazovaniya: perspektiva kross-kouturnoy gramotnosty, Sbornik statey po materialam nauchno-prakticheskoy konferencii "Kross-kulturniy dialog: komparativnie issledovaniya v pedagogike I psokhologii". Vladimir: Nerl, 45-50. 
Lotman, M. Y. 1973. Semiotica kino i problemi kinoestetiki. Tallinn: Izdatelstvo Eesti Raamat.

McLuhan, M. 1994. Understanding Media: The Extensions of Man. Cambridge: The MIT Press.

Mitkus, T. 2013. Komiksai Lietuvoje: nepanaudotas kultūrinis ir edukacinis įrankis, Santalka: filosofija, komunikacija 21(1): 21-34. http://dx.doi.org/10.3846/cpc.2013.03

Naydenyshev, K. V. 2011. Internet kak javleniye informatsionnoy kulturi 1990-2000 gg., Izvestiya Rossiyskogo gosudarstvennogo pedagogicheskogo universitets im. A. I. Gertsena 132: 147-152.

Okpara, F. O. 2007. The Value of Creativity and Innovation in Entrepreneurship, Journal of Asia Entrepreneurship and Sustainability 3(2): 2-14.

Pine, II B. J.; Gilmore, J. H. 1999. The Experience Economy: Work Is Theatre \& Every Business a Stage. Boston: Harvard Business School Press.

Ridderstråle, J.; Nordström, K. 2002. Funky Business: Talent Makes Capital Dance. Edinburgh: Pearson Education.

Rosen, L. D. 2007. Me, My Space, and I: Parenting the Net Generation. New York, N. Y.: Palgrave Macmillan.

Sadokhin, A. P. 2004. Mezhkulturnaya kommunikatsiya: uchebnoe posobie. Moscow: Alfa-M, INFRA-M.

Weinacht, T.; Umutoni, D.; Mwema, P.; Huwe, I. 2009. CINEDUC - Education through Cinema: Introduction and Guide to the Method. Eschborn: GTZ.

Wood, Ph. 2004. Krugovorot gorodskogo tvorchestva, in Zelentsova, E. V. (Ed.). Tvorcheskie industrii v Rossii. Moscow: Institut kulturnoy politiki, 35-43.

Zelentsova, E.; Gladkih, N. 2010. Tvorcheskie industrii: teorii I praktiki. Moscow: Izdatelskiy dom "Klassika XXI".

\title{
FILMŲ ANALIZĖ KAIP KŪRYBINIŲ TARPKULTŪRINIŲ GEBĖJIMŲ FORMAVIMOSI ŠALTINIS DAUGIAKULTŪRIAME KONTEKSTE
}

\author{
Liudmila STAROSTOVA, Larisa PISKUNOVA
}

\begin{abstract}
Santrauka
Autorès siekia pažvelgti i kiną ugdymo proceso metu, ji potencialiai taikant kaip kūrybinių tarpkultūrinių kompetencijų formavimo priemonę. Nūdien kinas nèra vien tik sintetinis menas, jis giliai integruotas i pamatinę moderniosios kultūros struktūrą, o jo formos gali tapti efektyviu ugdymo inovacijų šaltiniu. Straipsnyje pateikiama filmų analizès samprata kaip nuoroda i metodini kino panaudojimą ugdant. Skirtingų kino atvejų įtraukimo i̇ praktines pamokas analizė autorèms leido pagrịsti ryši tarp filmų analizès metodo ir moksleivių kūrybinių tarpkultūrinių gebėjimų formavimosi. Kaip teigiama straipsnyje, autoriu panaudotos filmų analizès metodo technikos padeda plètotis moksleiviu tarpkultūrinèms kompetencijoms, svarbioms jų profesinei ir kasdienei veiklai daugiakultūriame kontekste.

Reikšminiai žodžiai: kinas, kūrybiniai tarpkultūriniai gebejjimai, švietimas, filmas, filmų analizè, daugiakultūris kontekstas, mokymo metodas.
\end{abstract}

